\title{
Inducible UV repair potential of Pseudomonas aeruginosa PAO
}

\author{
C. Sue Simonson, ${ }^{1}$ Tyler A. KoKJohn ${ }^{1,2} \dagger$ and Robert V. Miller ${ }^{1,2 *}$ \\ ${ }^{1}$ Department of Biochemistry and ${ }^{2}$ Program in Molecular Biology, Stritch School of Medicine, Loyola University \\ Chicago, Maywood, Illinois, 60153, USA
}

(Received 22 January 1990; revised 12 March 1990; accepted 2 April 1990)

\begin{abstract}
Pseudomonas aeruginosa PAO lacks UV-inducible Weigle reactivation and Weigle mutagenesis of UV-damaged bacteriophages. This lack of UV-inducible, error-prone DNA repair appears to be due to the absence of efficiently expressed umuDC-like genes in this species. When the $P$. aeruginosa rec $A$ gene is introduced into a rec $A$ (Def) mutant of Escherichia coli K12, the $P$. aeruginosa $\operatorname{rec} A$ gene product is capable of mediating $U V$-induced mutagenesis, indicating that it could participate in a $\operatorname{rec} A$-lex $A$-like regulatory network and function in inducible DNA repair pathways if such existed in $P$. aeruginosa. The presence of the IncP9, UV-resistance plasmid $R 2$ in RecA $^{+}$strains of $P$. aeruginosa PAO allows UV-inducible, mutagenic DNA repair of UV-irradiated bacteriophages. $R 2$ also greatly stimulates the ability of $U V$ radiation to induce mutagenesis of the bacterial chromosome. When $\mathrm{R} 2$ is introduced into $P$. aeruginosa strains containing either the rec $A 908$ or rec $A 102$ mutation, plasmid-mediated $U V$ resistance and Weigle reactivation are not observed. These observations suggest that the increased protection afforded to $P$. aeruginosa by $R 2$ is derived from a RecA-mediated, DNA-damage-inducible, error-prone DNA repair system which complements the lack of a chromosomally encoded umuDC-like operon.
\end{abstract}

\section{Introduction}

All living organisms must respond to stresses in their environment which challenge the integrity of their genetic material. One of the most pervasive of the stresses with which free-living organisms, particularly those in aquatic environments, must deal is DNA damage of the type produced by UV radiation. To date, the most studied and best understood system of responses to this stress has been that of the enteric bacterium Escherichia coli (Walker, 1984). E. coli K12 responds to UV challenge by inducing a repertoire of DNA repair systems which are collectively part of the SOS regulatory network (Little \& Mount, 1982; Walker, 1984). The expression of these responses is negatively regulated by the product of the lexA gene and positively regulated by stress-induced activation of the product of the rec $A$ gene. The most characteristic of the SOS-controlled repair systems is an error-prone system which requires the gene products of the chromosomal operon umuDC (Walker, 1984).

Very little is known about the physiological response

† Present address: Argonne National Laboratory, Environmental Research Division, 9700 S. Cass Ave, Bldg 203, Argonne, IL 60439, USA.

Abbreviation: Hcr, host-cell reactivation. of autochthonous soil and aquatic micro-organisms such as Pseudomonas aeruginosa to UV irradiation. The molecular basis for the repair of damage done to DNA by this type of stress has not been explored in these species. $P$. aeruginosa has been observed to be relatively sensitive to (Kung \& Lee, 1973; Krishnapillai, 1975; Kokjohn \& Miller, 1985; McBeth, 1989) and non-mutable by (Lehrbach et al., 1979; McBeth, 1989) UV radiation. Mutations in various loci, including recA (Kokjohn \& Miller, 1987, 1988; Horn \& Ohman, 1988), which increase the UV sensitivity of this species have been isolated (Krishnapillai, 1975).

In addition to chromosomally-encoded DNA repair systems, various plasmids, such as R46, increase the UV resistance of several enteric species including $E$. coli and Salmonella typhimurium (Langer et al., 1981; Walker, 1984; Sedgwick \& Goodwin, 1985). This plasmid contains genes (mucA and $m u c B$ ) which code for a mutagenic UV-repair system analogous to the $u m u D C$ encoded system of the E. coli chromosome (Elledge \& Walker, 1983). Many aquatic species of bacteria including $P$. aeruginosa harbour plasmids that encode fuctions that afford increased protection of the host to UV irradiation (Krishnapillai, 1975; Lehrbach et al., 1978; Jacoby et al., 1983; Bale et al., 1988).

In this study, we investigated the ability of UV radiation to induce increased DNA repair potential in $P$. 
Table 1. Bacterial strains and plasmids used in this study

\begin{tabular}{|c|c|c|}
\hline Strain or plasmid & Relevant genotype or phenotype & Source \\
\hline $\begin{array}{l}\text { P. aeruginosa } \\
\text { PAO1 } \\
\text { PAO25 } \\
\text { PAO303 } \\
\text { RM8 } \\
\text { RM265 }\end{array}$ & $\begin{array}{l}\text { Prototrophic } \\
\text { argF10 leu-10 } \\
\text { argB21 } \\
\text { argB21 recA } 908 \\
\text { leu-10 rec } A 102\end{array}$ & $\begin{array}{l}\text { Miller \& Ku (1978) } \\
\text { Kokjohn \& Miller (1987) } \\
\text { Kokjohn \& Miller (1988) } \\
\text { Kokjohn \& Miller (1988) } \\
\text { Kokjohn \& Miller (1987) }\end{array}$ \\
\hline $\begin{array}{l}\text { E. coli } \\
\text { AB1157 } \\
\text { JC2926 }\end{array}$ & $\begin{array}{l}\text { argE3 his-4 leu-6 proA2 trp-1 thi-1 supE44 } \\
\text { As AB1157 but recA13 }\end{array}$ & $\begin{array}{l}\text { Kokjohn \& Miller (1987) } \\
\text { Kokjohn \& Miller (1987) }\end{array}$ \\
\hline $\begin{array}{l}\text { Plasmids } \\
\text { R2 } \\
\text { pCP13 } \\
\text { pJC859 } \\
\text { pKML3001 } \\
\text { pKML3002 }\end{array}$ & $\begin{array}{l}I^{\prime} P 9, C^{R} S^{R} S^{R} U^{R} \\
T c^{R} \mathrm{Km}^{R} \text {, broad-host-range cosmid } \\
\text { pBR322 containing the } E \text {. coli rec } A \text { gene } \\
\text { pCP13 containing the } P \text {. aeruginosa rec } A \text { gene } \\
\text { pCP13 containing the } E \text {. coli rec } A \text { gene from pJC859 }\end{array}$ & $\begin{array}{l}\text { Jacoby (1977); Korfhagen et al. (1978) } \\
\text { Darzins \& Chakrabarty (1984) } \\
\text { Kokjohn \& Miller (1987) } \\
\text { Kokjohn \& Miller (1987) } \\
\text { This study }\end{array}$ \\
\hline
\end{tabular}

aeruginosa PAO in the form of Weigle reactivation and Weigle mutagenesis (Weigle, 1953) of UV-damaged $P$. aeruginosa bacteriophage D3 and F116 DNA. In addition, the inducible nature of the UV-resistance system encoded by the $P$. aeruginosa IncP9 UVresistance $\left(\mathrm{UV}^{\mathrm{R}}\right.$ ) plasmid R2 (Jacoby, 1977; Korfhagen et al., 1978) has been explored. In the absence of R2, significant levels of Weigle reactivation and Weigle mutagenesis could not be detected. R2 was found to encode a true UV-inducible, mutagenic DNA repair system which allows both Weigle reactivation and Weigle mutagenesis of UV-damaged phage DNAs.

\section{Methods}

Bacteria, bacteriophages, plasmids and media. Bacterial strains and plasmids used in this study are listed in Table 1. Bacteriophages D3 and F116L have been described (Miller \& Ku, 1978). Bacteria were maintained in Luria Broth (LB) (Miller \& Ku, 1978). Antibiotics were routinely used for selection at the following concentrations: $300 \mu \mathrm{g}$ carbenicillin $\mathrm{ml}^{-1}, 75 \mu \mathrm{g}$ rifampicin $\mathrm{ml}^{-1}$ and $750 \mu \mathrm{g}$ streptomycin $\mathrm{ml}^{-1}$. Tetracycline was used at a concentration of $15 \mu \mathrm{g} \mathrm{ml}^{-1}$ for $E$. coli and $250 \mu \mathrm{g} \mathrm{ml}^{-1}$ for $P$. aeruginosa. Plating of bacterial strains was done on LBA (LB containing $1.3 \%$, w/v, agar). Lysates of bacteriophages were prepared by the method of Miller \& Ku (1978). Strains containing plasmid $\mathrm{R} 2$ were constructed by conjugal transfer of the plasmid using the method of Miller \& Ku (1978).

$U V$ sensitivity. Cells were grown to early exponential phase (approximately $10^{8}$ c.f.u. $\mathrm{ml}^{-1}$ ) in LB at $37^{\circ} \mathrm{C}$. For strains containing $\mathrm{R} 2$, carbenicillin was present during this growth. Cultures were harvested by centrifugation at $5000 \mathrm{~g}$ in a Sorvall GLC-2B centrifuge. The cells were suspended in $0.85 \% \mathrm{NaCl}$ and $1.0 \mathrm{ml}$ of this cell suspension was placed in a Petri dish $(10 \mathrm{~cm}$ diameter $)$ and exposed to various doses of UV radiation from a General Electric germicidal lamp. The intensity of the UV radiation was determined using a UVX radiometer (Ultra-Violet Products). Survivors were determined by plating appropriate dilutions of cells on LBA and incubating overnight at $37^{\circ} \mathrm{C}$. All manipulations and incubations subsequent to UV irradiation were carried out under conditions designed to minimize photoreactivation.

The UV-sensitivity coefficient $\left(S_{\mathrm{UV}}\right)$ was calculated from:

$$
\left.S_{\mathrm{UV}}=\ln [\text { (c.f.u. })_{\mathrm{d}} /(\text { c.f.u. })_{0}\right] / d
$$

where (c.f.u. $)_{0}$ is the concentration of c.f.u. in unexposed samples and (c.f.u.) $)_{\mathrm{d}}$ is the recoverable concentration after exposure to dose $d$ of $\mathrm{UV}$ radiation. The dose $(d)$ is expressed in $\mathrm{J} \mathrm{m}^{-2}$.

Host-cell reactivation. Host-cell reactivation (Hcr) was measured as described by Miller \& Ku (1978), using D3c, a clear-plaque morphology mutant of bacteriophage D3 (Miller \& Ku, 1978). Hcr was quantified by calculating the phage sensitivity coefficient $\left(P S_{U V}\right)$ from a formula similar to that for $S_{\mathrm{UV}}$.

Weigle reactivation and Weigle mutagenesis of bacteriophages. Lysates of phage $\mathrm{D} 3 \mathrm{c}\left(2 \times 10^{8}\right.$ p.f.u. $\left.\mathrm{ml}^{-1}\right)$ in TNM buffer (Cavenagh \& Miller, 1986) were irradiated with a dose of UV radiation which gave approximately $0.01 \%$ survival in an unirradiated host $\left(200\right.$ or $250 \mathrm{~J} \mathrm{~m}^{-2}$ depending upon the host strain) and diluted in TNM buffer. Bacteria were grown in LB to early exponential phase (approximately $2 \times 10^{8}$ c.f.u. $\mathrm{ml}^{-1}$ ), centrifuged, suspended in an equal volume of $0.85 \% \mathrm{NaCl}$, and exposed to various doses of UV radiation as described above. Onetenth millilitre samples of irradiated bacteria were mixed with the various dilutions of unirradiated or irradiated phage lysates and absorption was allowed to occur at $37^{\circ} \mathrm{C}$ for $10 \mathrm{~min}$ in the dark. Lambda top agar (Kokjohn \& Miller, 1985) was added, and the mixture was poured onto LBA plates and incubated overnight at $37^{\circ} \mathrm{C}$ in the dark. Due to the high UV sensitivity of RecA ${ }^{-}$strains, approximately $10^{6}$ c.f.u. of unirradiated cells of the same strain were added at the time of plating of mixtures containing cells exposed to high doses of UV radiation $\left(>6 \mathrm{~J} \mathrm{~m}^{-2}\right)$. This allowed formation of a confluent lawn and ready detection of phage plaques.

The Weigle reactivation factor (WRF) was calculated from the formula:

$$
\begin{aligned}
& \text { WRF }=\left\{\left[(\text { p.f.u. })_{U v_{\phi}} /(\text { p.f.u. })_{0 \phi}\right]_{\text {on irradiated host }}\right\} / \\
& \left\{\left[(\text { p.f.u. })_{U V_{\phi}} /(\text { p.f.u. })_{0 \phi}\right]_{\text {on unirradiated host }}\right\}
\end{aligned}
$$

where (p.f.u.) $)_{U V \phi}$ is the titre of irradiated phages and (p.f.u. $)_{0 \phi}$ is the titre of the unirradiated lysate.

To determine UV-induced mutagenesis of phage DNA (Weigle mutagenesis), cell-free lysates of wild-type D3 were irradiated as 
described above and infected into UV-irradiated or unirradiated hosts. After overnight incubation in the dark, the frequency of clear-plaque mutants among surviving plaques was determined.

Chromosomal mutagenesis. (i) P. aeruginosa. Cells were grown in LB at $37^{\circ} \mathrm{C}$ to approximately $40 \mathrm{Klett}_{660}$ units. Cultures were harvested by centrifugation, suspended in an equal volume of $0.85 \% \mathrm{NaCl}$, and exposed to UV radiation. Samples from irradiated cultures were diluted in $0.85 \% \mathrm{NaCl}$ and plated on LBA to determine the percentage survival. Samples of the undiluted culture were also plated on LBA and incubated at $37^{\circ} \mathrm{C}$ for approximately $20 \mathrm{~h}$. At the end of this time, plates were replicated onto LBA containing rifampicin to enumerate rifampicin-resistant $\left(\right.$ Rif $\left.^{\mathrm{R}}\right)$ cells.

(ii) E. coli. Selection of mutants was by a modification of the method of Kato et al. (1977). Cell were grown at $37^{\circ} \mathrm{C}$ to mid-exponential phase in Pseudomonas Minimal Medium (PMM) (Miller \& Ku, 1978) containing $0.5 \%$ vitamin-free Casamino acids (Difco) and $0.4 \%$ glucose. Cultures were harvested by centrifugation, suspended in an equal volume of $0.85 \% \mathrm{NaCl}$, and exposed to $\mathrm{UV}$ radiation. Reversion to histidine prototrophy was assayed by plating samples on Low-His plates which contained PMM, $0 \cdot 4 \%$ glucose, and sufficient histidine to allow some doublings to take place before selection was exerted (Kato et al., 1977). Other required amino acids were present at $20 \mu \mathrm{g} \mathrm{ml}^{-1}$. The percentage survival was determined by plating dilutions of the irradiated culture on Low-His plates. At high dilution, $\mathrm{His}^{-}$colonies will grow to a sufficient size to be countable.

\section{Results}

\section{Dark repair potential}

We assessed the potential of isogenic $\mathrm{Rec}^{+}$and $\mathrm{Rec}^{-}$ strains of $P$. aeruginosa with and without the $U^{R}$ plasmid R2 to survive UV irradiation (Fig. 1, Table 2). $\mathrm{Rec}^{+}$(AB1157) and recA13 (JC2926) strains of E. coli were used as a comparison. Comparison of UVsensitivity coefficients revealed that $\operatorname{Rec}^{+}$strains of $P$. aeruginosa were approximately ten times more sensitive to UV irradiation than wild-type E. coli (Table 2). As has been previously reported (Kokjohn \& Miller, 1987, 1988), rec $A$ mutants of $P$. aeruginosa were more sensitive to UV radiation than their isogenic $\mathrm{Rec}^{+}$parents. However, the increase in sensitivity of rec $A$ mutants of $P$. aeruginosa was not as dramatic as observed in the $\mathrm{Rec}^{+}$ and $\operatorname{Rec} A^{-}$isogenic strains of E. coli.

When plasmid $\mathrm{R} 2$ was introduced into the $\mathrm{Rec}^{+}$ strains of $P$. aeruginosa, UV resistance was increased to levels approaching those of wild-type $E$. coli (Fig. 1, Table 2). No increase in UV resistance was observed after introduction of R2 into either of the $P$. aeruginosa recA mutants.

\section{Host-cell reactivation $(\mathrm{Hcr})$ of $U \mathrm{~V}$-damaged bacteriophages}

The UV resistance of an organism as measured by kill curves potentially includes constitutively expressed and damage-inducible components. To assess the constitu-

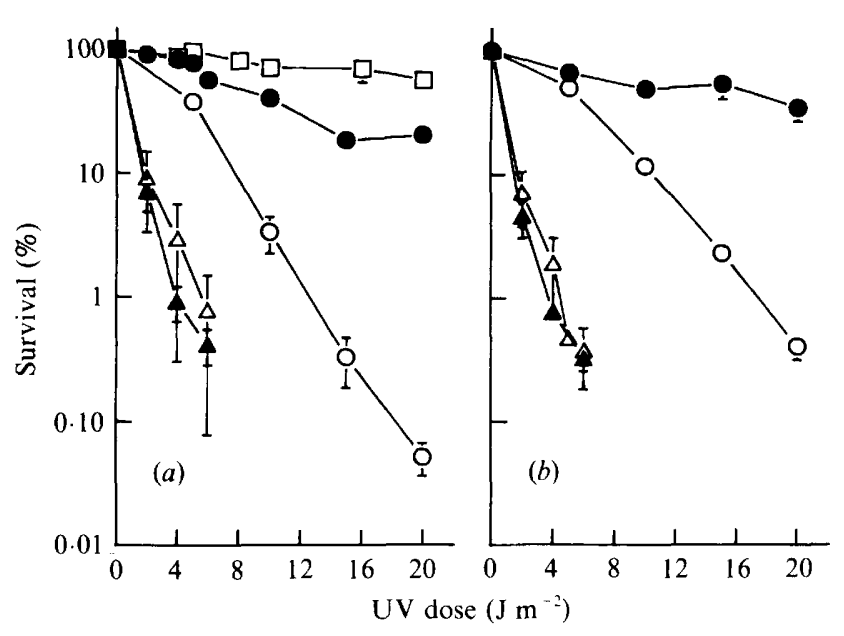

Fig. 1. UV sensitivity of various $P$. aeruginosa strains with and without R2. Cultures were grown to early exponential phase and exposed to various doses of UV radiation. The frequency of surviving cells was determined by plating on LB agar. Means and standard errors of at least three experiments are presented. (a) E. coli AB1157 ( $\square$ ), $P$. aeruginosa PAO303 $\left(\mathrm{Rec}^{+}\right)(\mathrm{O}), \mathrm{PAO} 303(\mathrm{R} 2)(\Theta), \mathrm{RM} 8(\mathrm{rec} A 908)(\triangle)$, RM8(R2) (A). (b) PAO25 (Rec $\left.{ }^{+}\right)(\mathrm{O})$, PAO25(R2) (O), RM265 (recA102) $(\triangle)$, RM265(R2) (A).

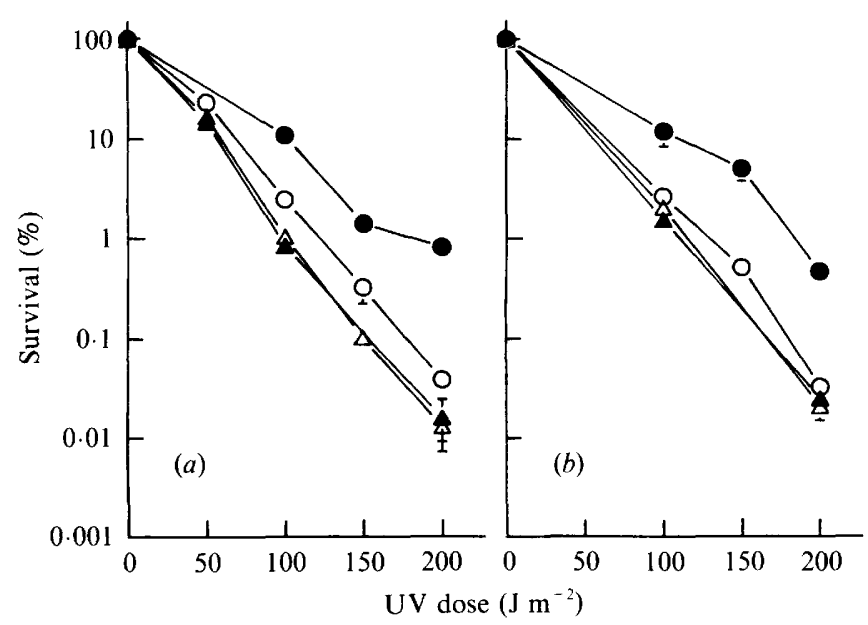

Fig. 2. Hcr of UV irradiated bacteriophage D3c. Bacteriophage lysates were exposed to various doses of UV radiation and used to infect unirradiated host cells. Means and standard errors of at least three experiments are presented. Hosts: (a) PAO303 $\left(\mathrm{Rec}^{+}\right)$(O) PAO303(R2) (O), RM8 (recA908) $(\triangle), \operatorname{RM8(R2)~(\Lambda ).~(b)~PAO25~}$ $\left(\mathrm{Rec}^{+}\right)(\mathrm{O}), \mathrm{PAO} 25(\mathrm{R} 2)(\mathrm{O}), \mathrm{RM} 265(\mathrm{rec} A 102)(\triangle), \mathrm{RM} 265(\mathrm{R} 2)(\mathbf{A})$.

tive component of the response of $P$. aeruginosa to UV-imposed DNA damage, a cell-free lysate of bacteriophage D3c was irradiated with various doses of UV radiation and the ability of $\mathrm{Rec}^{+}$and $\mathrm{Rec}^{-}$cells to repair the damage done to the phage genome was evaluated (Fig. 2, Table 2). The potential of each of the recA mutants to carry out $\mathrm{Hcr}$ was not reduced when compared to their isogenic $\operatorname{Rec} \mathrm{A}^{+}$parents. 
Table 2. Sensitivity of various strains to UV-induced damage

To determine the sensitivity of bacteria to UV radiation, cultures were grown to early exponential phase and exposed to various doses of UV radiation. Hcr was determined by exposing cell-free lysates of bacteriophage D3c to various doses of UV radiation and infecting unirradiated hosts. The UV dose for $1 \%$ survival of bacteria or bacteriophages was determined from plots like those displayed in Figs 1 and 2. The UV sensitivity coefficient $\left(S_{U V}\right)$ and phage sensitivity coefficient $\left(P S_{U V}\right)$ were determined from the formulae described in Methods.

\begin{tabular}{|c|c|c|c|c|c|}
\hline \multirow[b]{2}{*}{ Strain } & \multirow[b]{2}{*}{$\begin{array}{c}\text { Relevant } \\
\text { phenotype } \\
\text { or } \\
\text { genotype }\end{array}$} & \multicolumn{2}{|c|}{ UV sensitivity } & \multicolumn{2}{|c|}{ Her of phage D3c } \\
\hline & & $\begin{array}{l}\text { UV dose } \\
\text { for } 1 \% \\
\text { survival } \\
\left(\mathrm{J} \mathrm{m}^{-2}\right)\end{array}$ & $S_{\mathrm{UV}}$ & $\begin{array}{l}\text { UV dose } \\
\text { for } 1 \% \\
\text { survival } \\
\left(\mathrm{J} \mathrm{m}^{-2}\right)\end{array}$ & $P S_{\mathrm{UV}}$ \\
\hline \multicolumn{6}{|l|}{ E. coli } \\
\hline AB1157 & $\operatorname{Rec}^{+}$ & 152 & -0.030 & ND & ND \\
\hline JC2926 & $\operatorname{recA13}$ & $3 \cdot 0$ & -1.520 & ND & ND \\
\hline \multicolumn{6}{|l|}{ P. aeruginosa } \\
\hline PAO303 & $\operatorname{Rec}^{+}$ & $12 \cdot 4$ & -0.366 & 114 & -0.040 \\
\hline PAO25 & $\operatorname{Rec}^{+}$ & $17 \cdot 8$ & $-0 \cdot 268$ & 117 & -0.040 \\
\hline RM8 & $\operatorname{rec} A 908$ & $4 \cdot 4$ & $-1 \cdot 176$ & 102 & -0.044 \\
\hline RM265 & recA 102 & $5 \cdot 2$ & $-1 \cdot 136$ & 106 & -0.043 \\
\hline \multicolumn{6}{|l|}{$\begin{array}{r}\text { R2-containing } \\
P \text {. aeruginosa }\end{array}$} \\
\hline PAO303 (R2) & $\operatorname{Rec}^{+}$ & 60 & -0.077 & 183 & -0.024 \\
\hline PAO25 (R2) & $\operatorname{Rec}^{+}$ & 106 & -0.044 & 160 & -0.029 \\
\hline RM8(R2) & rec $A 908$ & $4 \cdot 4$ & $-1 \cdot 174$ & 95 & -0.049 \\
\hline RM265(R2) & recA102 & $4 \cdot 2$ & $-1 \cdot 169$ & 111 & -0.042 \\
\hline
\end{tabular}

ND, Not determined.

\section{Ability of $U V$ radiation to induce $D N A$ repair in $P$. aeruginosa}

In order to examine the inducible nature of DNA repair in $P$. aeruginosa, Weigle reactivation of UV-damaged bacteriophage D3c was assayed in various strains after exposure of the host cell to low doses of UV radiation. The phages were irradiated at a dose which produced approximately $0.01 \%$ survival in an unirradiated host strain, and the UV dose to the host was varied. Both $\mathrm{RecA}^{+}$strains and $\operatorname{recA}$ mutants showed only the slightest increases in the ability to reactivate UVdamaged phage DNA after exposure of the bacterium to UV radiation (Fig. 3). Similar results were obtained with UV-irradiated bacteriophage F116L (data not shown).

\section{Lack of $U V$-induced mutagenesis in P. aeruginosa}

Weigle mutagenesis of UV-damaged phage D3. Weigle mutagenesis was assayed by determining the frequency of clear-plaque morphology mutants among wild-type D3 phages repaired by host cells which had been exposed to low doses of UV radiation (Fig. 4). The spontaneous frequency of clear-plaque mutants among progeny phages repaired in $\operatorname{Rec}^{+}$and $\operatorname{rec} A$ mutants was the same $\left(1 \pm 0.5 \times 10^{-2}\right)$ and was consistent with rates previously reported (Egan \& Holloway, 1961). No increase in phage mutability was observed when the host bacterium was exposed to UV radiation.

Chromosomal mutagenesis. The frequency of $\mathrm{Rif}^{\mathrm{R}}$ cells was determined after exposure to various doses of UV radiation (Table 3). A slight induction of $\mathrm{R}^{\mathrm{R}}{ }^{\mathrm{R}}$ mutants was consistently observed.

Restoration of $U V$-induced mutagenesis of recA mutants of $E$. coli by functional P. aeruginosa RecA protein

From the data presented above, it appears that, unlike $E$. coli, $P$. aeruginosa PAO does not possess the ability to induce additional DNA-repair capacity following exposure to UV irradiation. However, there are at least two explanations for this apparent lack of UV-inducible repair. First, the $P$. aeruginosa chromosome may lack functioning structural genes for DNA-damage-inducible repair (e.g. umuDC analogues). Second, the genes may be present, but the $P$. aeruginosa $\operatorname{rec} A$ gene product is incapable of regulating their expression.

We have previously cloned the $P$. aeruginosa rec $A$ gene and demonstrated that it restores recombinational proficiency and UV resistance to rec $A$ mutants of $E$. coli (Kokjohn \& Miller, 1985, 1987). To determine if the $P$. 


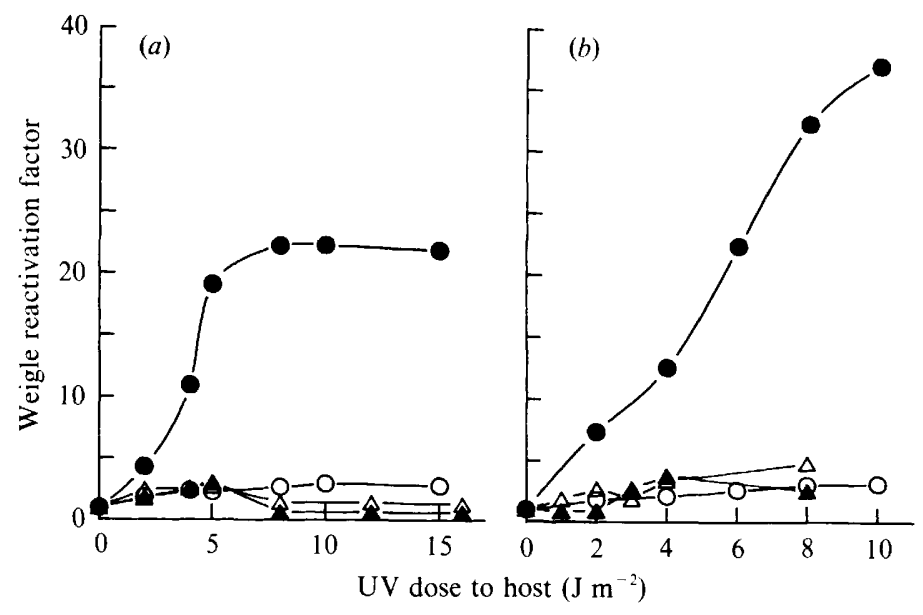

Fig. 3

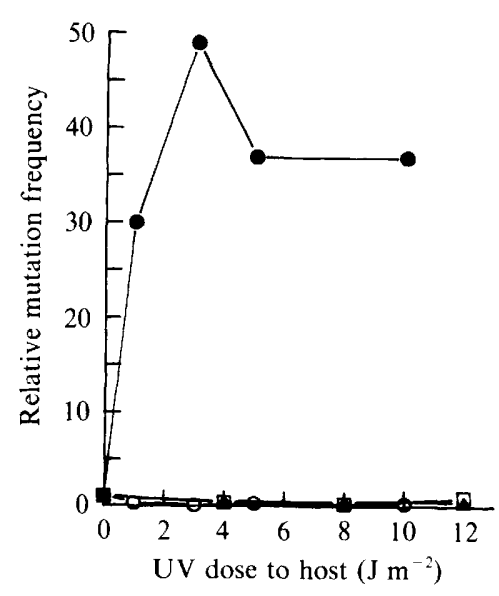

Fig. 4

Fig. 3. Weigle reactivation of UV-irradiated bacteriophage D3c. Irradiated and unirradiated bacteriophages were used to infect host bacteria which had been exposed to various low doses of UV radiation. The Weigle reactivation factor (WRF) was calculated from the formula given in Methods and is a measure of the inducible DNA repair capacity of the host cell. Means of at least three experiments are plotted. Error bars omitted for clarity. The difference in the WRF for PAO303(R2)/PAO303 and for PAO25(R2)/PAO25 at $2 \mathrm{~J} \mathrm{~m}^{-2}$ was

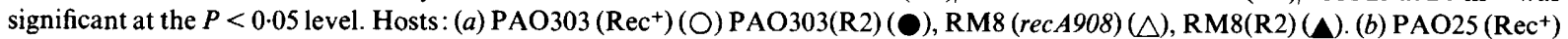
(O), PAO25(R2) (O), RM265 (recA102) ( $\triangle$ ), RM265(R2) (A).

Fig. 4. Weigle mutagenesis of UV-irradiated bacteriophage D3. The fraction of progeny phage showing clear-plaque morphology was calculated in experiments conducted as described in Fig. 3. A representative experiment is presented. Data from other experiments were qualitatively the same. PAO25 $\left(\operatorname{Rec}^{+}\right)(0)$, PAO25(R2) (O), RM265 (recA102) ( $\square$ ), RM265(R2) (A).

Table 3. R2-stimulated, $U V$-induced mutagenesis of the $P$. aeruginosa chromosome

Cultures were grown to early exponential phase and exposed to various doses of UV radiation. Survival rates and numbers of rifampicin-resistant $\left(\right.$ Rif $\left.^{\mathrm{R}}\right)$ mutants were determined by differential plating. Two representative experiments are shown.

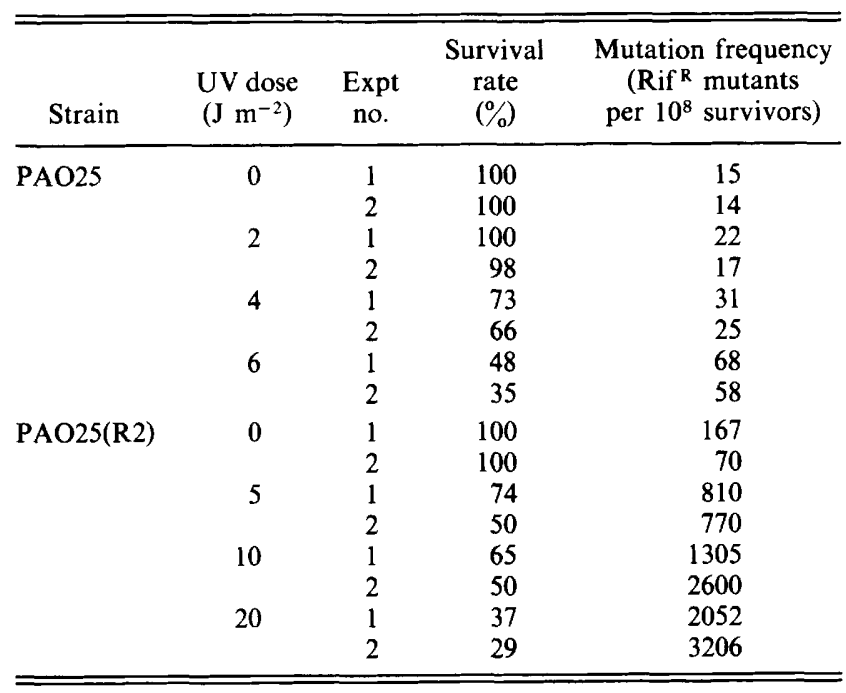

aeruginosa $\operatorname{Rec} \mathrm{A}$ protein is capable of inducing mutagenic repair in a species known to contain functional umuDC genes, we introduced our clone of the gene into E. coli JC2926, a recA13 derivative of AB1157. E. coli
recA13 strains are non-mutable by UV irradiation. The reversion frequency of the his-4 allele in recA13 mutants is $<1 \times 10^{-8}$ (Kato et al., 1977).

The presence of the $P$. aeruginosa rec $A$ gene in the lowcopy-number plasmid pKML3001 (Kokjohn \& Miller, 1987) restored the UV mutability of the his-4 allele of JC2926 (Table 4). The levels of induced mutagenesis were equivalent to the levels obtained when the $E$. coli rec $A$ gene, cloned into the same vector (pKML3002), was introduced into JC2926 and to the levels observed with the $\mathrm{Rec}^{+}$parental strain AB1157.

\section{Plasmid-mediated reactivation of UV-irradiated bacteriophages}

Expression of plasmid-encoded UV-inducible repair systems such as the $m u c A B$ system of R46 is controlled by the SOS regulatory system in $E$. coli (Elledge \& Walker, 1983). Since it appeared that the $P$. aeruginosa rec $A$ gene was capable of regulating gene expression in response to UV exposure, we investigated whether R2-augmented UV resistance in $P$. aeruginosa was inducible and dependent on a functional RecA protein. To determine if R2-dependent UV resistance was due to the augmentation of the constitutively expressed repair capabilities of $P$. aeruginosa, the ability of cells containing plasmid R2 to repair UV-damaged phage genomes was evaluated as 
Table 4. Restoration of $U V$-induced mutagenesis of $E$. coli recA13 mutants by the cloned $P$. aeruginosa gene

Cultures were grown to early exponential phase and exposed to various doses of UV radiation. Survival rates and numbers of histidine prototrophic revertants of the his- 4 allele were determined by differential plating. pKML3001 contains the $P$. aeruginosa rec $A$ gene, and pKML3002 contains the $E$. coli rec $A$ gene. Two representative experiments are shown.

\begin{tabular}{|c|c|c|c|c|}
\hline Strain & $\begin{array}{l}\text { UV dose } \\
\left(\mathrm{J} \mathrm{m}^{-2}\right)\end{array}$ & $\begin{array}{c}\text { Expt } \\
\text { no. }\end{array}$ & $\begin{array}{l}\text { Survival } \\
\text { rate } \\
(\%)\end{array}$ & $\begin{array}{c}\text { Mutation frequency } \\
\text { (His } \text { (Hutants }^{+} \text {mut } \\
\text { per } 10^{8} \text { survivors) }\end{array}$ \\
\hline $\begin{array}{l}\mathrm{JC2926(pKML3001)} \\
(\operatorname{rec} A 13)\end{array}$ & $\begin{array}{r}0 \\
5 \\
10 \\
20\end{array}$ & $\begin{array}{l}1 \\
2 \\
1 \\
2 \\
1 \\
2 \\
1 \\
2\end{array}$ & $\begin{array}{r}100 \\
100 \\
100 \\
90 \\
73 \\
65 \\
37 \\
48\end{array}$ & $\begin{array}{r}1 \cdot 2 \\
13 \\
135 \\
134 \\
345 \\
355 \\
1778 \\
1292\end{array}$ \\
\hline JC2926(pKML3002) & $\begin{array}{c}0 \\
5 \\
10 \\
20\end{array}$ & $\begin{array}{l}1 \\
2 \\
1 \\
2 \\
1 \\
2 \\
1 \\
2\end{array}$ & $\begin{array}{r}100 \\
100 \\
73 \\
70 \\
38 \\
30 \\
27 \\
20\end{array}$ & $\begin{array}{r}3 \\
11 \\
45 \\
72 \\
126 \\
400 \\
294 \\
588\end{array}$ \\
\hline $\mathrm{AB} 1157\left(\operatorname{Rec}^{+}\right)$ & $\begin{array}{c}0 \\
5 \\
10 \\
20\end{array}$ & $\begin{array}{l}1 \\
2 \\
1 \\
2 \\
1 \\
2 \\
1 \\
2\end{array}$ & $\begin{array}{r}100 \\
100 \\
100 \\
74 \\
100 \\
43 \\
40 \\
31\end{array}$ & $\begin{array}{r}23 \\
30 \\
50 \\
52 \\
164 \\
360 \\
720 \\
741\end{array}$ \\
\hline
\end{tabular}

described above for Hcr (Fig. 2). The presence of R2 increased the potential of $\mathrm{Rec}^{+}$hosts to repair UVdamaged phage DNA only slightly (Table 2). This suggests that the majority of increased UV resistance conferred by $\mathrm{R} 2$ is due to a damage-inducible system (or systems) of repair. No increase in plasmid-mediated reactivation was observed in $\mathrm{R} 2$-containing $\operatorname{rec} A$ mutants. Similar results were obtained when UVdamaged F116L phages were assayed in the same manner (data not shown).

\section{$R 2$-mediated Weigle reactivation of $U V$-damaged $D 3 c$ phages}

The presence of $\mathrm{R} 2$ in $\mathrm{Rec} \mathrm{A}^{+}$strains allowed for Weigle reactivation of $U V$-irradiated D3c phages (Fig. 3). The rec $A$ mutants did not exhibit Weigle reactivation even when R2 was present. Weigle reactivation of irradiated F116L phages was also observed in $\mathrm{RecA}^{+}$strains containing $\mathrm{R} 2$, but not in plasmid-free isogens (data not shown).

\section{Mutagenic nature of R2-mediated UV-repair}

Weigle mutagenesis of UV-damaged phage D3. When R2 was introduced into $\mathrm{RecA}^{+}$cells, the level of clear-plaque mutants among the progeny of phages repaired in unirradiated hosts was not affected $\left(1 \pm 0.5 \times 10^{-2}\right)$. However, increased mutagenesis was observed after exposure of the plasmid-containing host to UV (Fig. 4). No increase in mutation frequency was observed in a rec $A$ mutant containing $\mathrm{R} 2$.

Chromosomal mutagenesis. The frequency of $\mathrm{Rif}^{\mathrm{R}}$ survivors of UV irradiation was determined in R2-containing strains (Table 3). At equivalent levels of survival, chromosomal mutagenesis was strikingly augmented over rates obtained without the plasmid. Both spontaneous and UV-stimulated frequencies were increased.

\section{Discussion}

$P$. aeruginosa is surprisingly sensitive to $\mathrm{UV}$ irradiation when compared to E. coli. As a natural member of soil 
and aquatic microbial communities, $P$. aeruginosa is continually exposed to a variety of physical and chemical agents which cause DNA damage similar to that produced by UV radiation (Peak \& Peak, 1989). The lack of DNA repair potential in $P$. aeruginosa would not be predicted since it appears that this species' needs for stress-inducible repair capacity is certainly as great as and possibly greater than that of $E$. coli.

While $\mathrm{RecA}^{+}$strains of $P$. aeruginosa PAO are approximately ten times more sensitive to $\mathrm{UV}$ radiation than are $\mathrm{RecA}^{+}$strains of $E$. coli, recA mutants of $E$. coli and $P$. aeruginosa display similar levels of sensitivity (Fig. 1, Table 2). At the same time, the potential for $\mathrm{RecA}^{+}$and $\operatorname{RecA}^{-}$isogens of $P$. aeruginosa to host-cellreactivate $\mathrm{UV}$-damaged bacteriophages is equivalent (Fig. 2, Table 2). These observations suggest that one or more rec $A$-dependent, inducible repair systems which exist in $E$. coli are lacking in $P$. aeruginosa PAO.

In $E$. coli, Weigle reactivation and UV-induced mutagenesis are dependent on the products of at least four genes, $\operatorname{rec} A$, lexA, umuD and umuC (Kato, et al., 1977). The products of the recA and lexA genes regulate these processes as part of the SOS network. The induction of expression of these systems is mediated by the RecA protein, which stimulates cleavage of the repressor of the network, LexA protein, following exposure of the cell to UV radiation (Little et al., 1980; Little \& Mount, 1982; Walker, 1984). rec $A$ mutants of $E$. coli are incapable of inducing the SOS network (Walker, 1984). The products of the $u m u D C$ genes are structural components of the molecular processes underlying Weigle reactivation and UV-inducible mutagenesis (Kato \& Shinoura, 1977; Kato et al., 1977). In addition, the $\operatorname{Rec} A$ protein has one or more functional roles in these processes. RecA accelerates the post-translational auto-proteolytic activation of the UmuD protein and may have an additional function as well (Nohmi et al., 1988). Therefore, $\operatorname{rec} A(\mathrm{Def}) \operatorname{lex} A(\mathrm{Def})$ strains are nonmutable despite the absence of functional LexA (Nohmi et al., 1988).

$P$. aeruginosa PAO appears to lack both Weigle reactivation (Fig. 3) and Weigle mutagenesis (Fig. 4) of UV-damaged bacteriophages. UV-mediated mutagenesis of the bacterial chromosome is, at best, only slightly inducible in this species (Table 3). The lack, or low level of expression, of these processes in P. aeruginosa suggests that either (i) this bacterium lacks functional genes necessary for these repair systems (i.e. $u m u D C$ analogues), (ii) the expression of these systems is not under the control of a lexA-recA-like switch, or (iii) these systems are not induced by UV radiation.

Our laboratory has demonstrated that the cloned $P$. aeruginosa $\operatorname{rec} A$ gene, when introduced into $\operatorname{rec} A(\mathrm{Def})$ mutants of $E$. coli, is capable of regulating several SOS functions including UV-dependent activation of $\lambda$ prophages (Kokjohn \& Miller, 1985, 1987) and DNAdamage-inducible (din) gene expression (Kokjohn \& Miller, 1987). In $P$. aeruginosa, UV-dependent prophage activation is also regulated by the $\operatorname{RecA}$ protein (Kokjohn \& Miller, 1987, 1988), and expression of the rec $A$ gene itself is autoregulated and induced by DNAdamaging agents (Horn \& Ohman, 1988; Miller \& Kokjohn, 1988). Furthermore, the $E$. coli and $P$. aeruginosa RecA proteins apparently regulate UVstimulated activation of $\lambda$ prophages by a similar molecular mechanism (Kokjohn \& Miller, 1985, 1987). When present in $E$. coli, expression of the $P$. aeruginosa rec $A$ gene can be regulated by the LexA protein (Miller \& Kokjohn, 1988). Here we show that it also restores UVinducible mutagenesis in $E$. coli $\operatorname{rec} A(\mathrm{Def})$ mutants (Table 4), suggesting that it is also capable of fulfilling the functional roles of the E. coli RecA protein in SOS repair. Therefore, the $P$. aeruginosa RecA protein should be fully capable of participating in a recA-lexA-like regulatory switch and functioning in inducible DNA repair pathways if such exist in $P$. aeruginosa.

The $P$. aeruginosa-specific, IncP9 plasmid R2 dramatically increases the UV resistance of $\operatorname{Rec}^{+}$strains of $P$. aeruginosa (Fig. 1, Table 2) and allows for both Weigle reactivation and UV-induced mutagenesis in this species (Figs 3 and 4, Table 3). The phenotypic expression of these R2-encoded systems is dependent on UV irradiation of the host cell and on a $\operatorname{RecA}^{+}$phenotype. Our experiments demonstrate the potential of Pseudomonasspecific $U^{R}$ plasmids to mediate a true DNA-damageinducible mutagenic repair response to $\mathrm{UV}$ radiation.

The UVR plasmid R46 and its derivative pKM101 have been studied in detail in several enteric species (Langer et al., 1981; Elledge \& Walker, 1983; Walker, 1984). These plasmids harbour the $m u c A$ and $m u c B$ genes (Langer et al., 1981), which are structural and functional analogues of the E. coli chromosomal gene umuD and $u m u C$ respectively (Elledge \& Walker, 1983). Like $u m u D C$, expression of the UV-induced resistance and mutagenic functions encoded by mucAB is under the control of the $E$. coli lexA-rec $A$ regulatory switch. The dependence of expression of the $\mathrm{UV}^{\mathrm{R}}$ phenotype of $\mathrm{R} 2$ on a functional $P$. aeruginosa $\operatorname{Rec} A$ protein suggests that R2 harbours genes which are functional analogues of the $m u c A B$ genes of $\mathrm{R} 46$. This interpretation is supported by the observation that the $\mathrm{UV}^{\mathrm{R}}$ phenotype of R46 is also expressed in $P$. aeruginosa PAO after UV irradiation (T. A. Kokjohn \& R. V. Miller, unpublished).

Taken together, the observations reported here support the conclusion that $P$. aeruginosa PAO lacks active DNA-damage-inducible repair and mutagenesis pathways. This deficiency may be due either to the absence of structural genes required for these activities (e.g. umuDC 
analogues) or, if they are present, to their poor expression. In this respect, $P$. aeruginosa PAO may be similar to $S$. typhimurium LT2, which also shows only low levels of UV mutability and Weigle reactivation. It has been demonstrated recently that $S$. typhimurium contains $u m u D C$-like sequences which are only marginally functional, probably due to a naturally-occurring defect in the umuD-like gene (Smith \& Eisenstadt, 1989; Thomas \& Sedgwick, 1989).

For free-living soil and aquatic micro-organisms such as $P$. aeruginosa which lack significant levels of UVinducible DNA repair, $U^{R}$ plasmids may be of singular importance to the natural ecology of their host bacteria. In order to survive in their natural habitats, these microorganisms must cope with exposure to solar UV radiation. Since its lethal effects clearly extend to several metres below the water surface in some environments (Calkins et al., 1976; Bale et al., 1988), UVR plasmids potentially affect the structure of microbial communities in many aquatic habitats. In addition to the protection they afford the host organism, plasmids such as R2 are often conjugation-proficient (Krishnapillai, 1975) and can be efficiently transferred by transduction as well (Saye et al., 1987). The potential for dissemination of these plasmids through aquatic populations is significant since both conjugation (Bale et al., 1988; O'Morchoe et al., 1988) and transduction (Saye et al., 1987) have been shown to be effective mechanisms of plasmid transmission in natural freshwater populations of Pseudomonas and are operative under the conditions found in nature.

Because the repair systems encoded by $U^{\mathrm{R}}$ plasmids may be mutagenic, their presence may significantly increase the genetic diversity and rate of evolution of natural bacterial communities, at least on an episodic basis. An understanding of the responses of members of the natural aquatic microbiota to DNA-damaging stress and the potential role of $U^{R}$ plasmids in moulding natural bacterial populations is fundamental to the development of a true understanding of microbial ecology and the development of realistic models for evolutionary dynamics of free-living bacterial species.

This work was supported by a grant from the Dean's Development Fund, Stritch School of Medicine, and by cooperative agreements CR-815234 and CR-815282 from the Gulf Breeze Laboratory, US Environmental Protection Agency.

\section{References}

BALE, M. J., FRY, J. C. \& DAY, M. J. (1988). Transfer and occurrence of large mercury resistance plasmids in river epilithon. Applied and Environmental Microbiology 54, 972-978.

Calkins, J., Buckles, J. D. \& Mobller, J. R. (1976). The role of solar UV radiation in 'natural' water purification. Photochemistry and Photobiology 24. 49-57.
CavenaGh, M. M. \& MilleR, R. V. (1986). Specialized transduction of Pseudomonas aeruginosa PAO by bacteriophage D3. Journal of Bacteriology 165, 448-452.

Darzins, A. \& Chakrabarty, A. M. (1984). Cloning of genes controlling alginate biosynthesis from a mucoid cystic fibrosis isolate of Pseudomonas aeruginosa. Journal of Bacteriology 159, 9-18.

EGAN, J. B. \& HollowAY, B. W. (1961). Genetic studies on lysogeny in Pseudomonas aeruginosa. Australian Journal of Experimental Biology 39, 9-18.

ElledGe, S. J. \& WALKer, G. C. (1983). The mùc genes of pK M101 are induced by DNA damage. Journal of Bacteriology 155, 1306-1315.

HORN, J. M. \& OHMAN, D. E. (1988). Transcriptional and translational analysis of recA mutant alleles in Pseudomonas aeruginosa. Journal of Bacteriology 170, 1937-1950.

JACOBY, G. A. (1977). Classification of plasmids in Pseudomonas aeruginosa. In Microbiology 1977, pp. 119-126. Edited by D. Schlessinger. Washington, DC: American Society for Microbiology.

JaCoby, G. A., Sutton, L., KNOBel, L. \& MAMmen, P. (1983). Properties of IncP-2 plasmids of Pseudomonas spp. Antimicrobial Agents and Chemotherapy 24, 168-175.

KaTo, T. \& SHINOURA, Y. (1977). Isolation and characterization of mutants of Escherichia coli deficient in induction of mutations by ultraviolet light. Molecular and General Genetics 156, 121-131.

Kato, T., Rothman, R. H. \& Clark, A. J. (1977). Analysis of the role of recombination and repair in mutagenesis of Escherichia coli by UV irradiation. Genetics 87, 1-18.

KoKJoHN, T. A. \& Miller, R. V. (1985). Molecular cloning and characterization of the recA gene of Pseudomonas aeruginosa PAO. Journal of Bacteriology 163, 568-572.

KokJohn, T. A. \& Miller, R. V. (1987). Characterization of the Pseudomonas aeruginosa recA analogue and its protein product: rec102 is a mutant allele of the $P$. aeruginosa PAO recA gene. Journal of Bacteriology 169, 1499-1508.

KoKJoHN, T. A. \& MilleR, R. V. (1988). Characterization of the Pseudomonas aeruginosa recA gene: the Les ${ }^{-}$phenotype. Journal of Bacteriology 170, 578-582.

KORFHAGEN, T. R., SUTTON, L. \& JACOBY, G. A. (1978). Classification and physical properties of Pseudomonas plasmids. In Microbiology 1978 , pp. 221-224. Edited by D. Schlessinger. Washington, DC: American Society for Microbiology.

KrishNAPILLAI, V. (1975). Resistance to ultraviolet light and enhanced mutagenesis conferred by Pseudomonas aeruginosa plasmids. Mutation Research 29, 363-372.

Kung, A. H. C. \& Less, B. T. O. (1973). The isolation and characterization of radiation and chemical mutagen sensitive mutants of Pseudomonas aeruginosa. Mutation Research 20, 175-190.

Langer, P. J., Shanabruch, W. G. \& Walker, G. C. (1981). Functional organization of plasmid pKM101. Journal of Bacteriology 145, 1310-1316.

Lehrbach, P. R., Kung, A. H. C. \& LeE, B. T. O. (1978). R plasmids which alter ultraviolet light-sensitivity and enhance ultraviolet lightinduced mutability in Pseudomonas aeruginosa. Journal of General Microbiology 108, 119-123.

Lehrbach, P. R., Lee, B. T. O. \& Dirckze, C. D. (1979). Effect of repair deficiency and $\mathbf{R}$ plasmids on spontaneous and radiationinduced mutability in Pseudomonas aeruginosa. Journal of Bacteriology 139, 953-960.

LITTLE, J. W. \& MOUNT, D. W. (1982). The SOS regulatory system of Escherichia coli. Cell 29, 11-22.

Little, J. W., Edmiston, S. H., Pacelli, L. Z. \& Mount, D. W. (1980). Cleavage of the Escherichia coli lexA protein by the recA protease. Proceedings of the National Academy of Sciences of the United States of America 77, 3225-3229.

MCBETH, D. L. (1989). Effect of degradative plasmid CAM-OCT on responses of Pseudomonas bacteria to UV light. Journal of Bacteriology 171, 975-982.

MILLER, R. V. \& KoKJOHN, T. A. (1988). Expression of the recA gene of Pseudomonas aeruginosa PAO is inducible by DNA-damaging agents. Journal of Bacteriology 170, 2385-2387.

MILLER, R. V. \& KU, C.-M. C. (1978). Characterization of Pseudomonas aeruginosa mutants deficient in the establishment of lysogeny. Journal of Bacteriology 134, 875-883. 
Nohmi, T., Battista, J. R., Dodson, L. A. \& Walker, G. C. (1988). RecA-mediated cleavage activates UmuD for mutagenesis: mechanistic relationship between transcriptional derepression and posttranslational activation. Proceedings of the National Academy of Sciences of the United States of America 85, 1816-1820.

O'Morchoe, S. M., Ogunseitan, O., Sayler, G. S. \& Miller, R. V. (1988). Conjugal transfer of R68.45 and FP5 between Pseudomonas aeruginosa strains in a freshwater environment. Applied and Environmental Microbiology 54, 1923-1929.

Peak, M. J. \& Peak, J. G. (1989). Solar-ultraviolet-induced damage to DNA. Photodermatology 6, 1-15.

Saye, D. J., Ogunseitan, O., SAyler, G. S. \& Miller, R. V. (1987). Potential for transduction of plasmids in a natural freshwater environment: effect of donor concentration and a natural microbial community on transduction in Pseudomonas aeruginosa. Applied and Environmental Microbiology 53, 987-995.
SEDGwiCK, S. G. \& Goodwin, P. A. (1985). Differences in mutagenic and recombinational repair in enterobacteria. Proceedings of the National Academy of Sciences of the United States of America 82, $4172-4176$

SMith, C. M. \& Eisenstadt, E. (1989). Identification of a $u m u D C$ locus in Salmonella typhimurium LT2. Journal of Bacteriology 171, $3860-3865$.

Thomas, S. M. \& Sedgwick, S. G. (1989). Cloning of Salmonella typhimurium DNA encoding mutagenic DNA repair. Journal of Bacteriology 171, 5776-5782.

WalKer, G. C. (1984). Mutagenesis and inducible responses to deoxyribonucleic acid damage in Escherichia coli. Microbiological Reviews 48, 60-93.

WEIGLE, J. J. (1953). Induction of mutation in a bacterial virus. Proceedings of the National Academy of Sciences of the United States of America 39, 628-636. 